\title{
Differential regulation of antioxidant enzymes in Frankliniella occidentalis (Thysanoptera: Thripidae) exposed to thermal stress
}

\author{
Jia-Wen Yuan $^{1}$, Yutao Zheng ${ }^{1}$, Ya-Wen Chang ${ }^{1}$, Jing Bai $^{1}$, Jing Qin ${ }^{1}$, Yu-Zhou Du ${ }^{\text {Corresp. } 1,2}$ \\ ${ }^{1}$ College of Horticulture and Plant Protection \& Institute of Applied Entomology, Yangzhou University, Yangzhou, China \\ 2 Joint International Research Laboratory of Agriculture and Agri-Product Safety, Yangzhou University, Yangzhou, China \\ Corresponding Author: Yu-Zhou Du \\ Email address: yzdu@yzu.edu.cn
}

Frankliniella occidentalis is an invasive insect pest that incites damage to ornamental and agronomic crops on a global scale. In this study, the effects of temperature on gene expression and enzyme activity were studied for superoxide dismutase (SOD), peroxidase (POD), and glutathione-S-transferase (GST) in F. occidentalis. SOD, POD and GST enzyme activity increased significantly at $35-37^{\circ} \mathrm{C}$ but declined as the temperature increased to $41^{\circ} \mathrm{C}$. In a time course study at $35^{\circ} \mathrm{C}, \mathrm{SOD}, \mathrm{POD}$ and GST activities were significantly elevated at $0.5,1$ and $2 \mathrm{~h}$ in comparison to the control at $26^{\circ} \mathrm{C}$. Expression patterns were evaluated for the three antioxidant genes under high and low temperature stress. In a time course study at $-4^{\circ} \mathrm{C}, S O D, P O D$ and GST expression peaked at $1 \mathrm{~h}$ and declined at $2 \mathrm{~h}$ of exposure. In contrast, when transcription was monitored at $35^{\circ} \mathrm{C}$, expression was lowest at $1 \mathrm{~h}$ and increased at $2 \mathrm{~h}$. The results provide data that will be useful in deciphering the role of antioxidant enzymes in the adaptation of $F$. occidentalis to climate change. 
1 Differential regulation of antioxidant enzymes in Frankliniella occidentalis

\section{2 (Thysanoptera: Thripidae) exposed to thermal stress}

3

4 Jia-Wen Yuan ${ }^{1}$, Yu-Tao Zheng ${ }^{1}$, Ya-Wen Chang ${ }^{1}$, Jing Bai ${ }^{1}$, Jing Qin ${ }^{1}$, Yu-Zhou Du${ }^{1,2}$

5

$6{ }^{1}$ School of Horticulture and Plant Protection \& Institute of Applied Entomology, Yangzhou

7 University, Yangzhou 225009, P. R. China

82 Joint International Research Laboratory of Agriculture and Agri-Product Safety, Yangzhou

9 University, Yangzhou 225009, P. R. China

10

11 Corresponding author: Yu-Zhou Du, e-mail:yzdu@yzu.edu.cn

12

13 


\section{Abstract}

15 Frankliniella occidentalis is an invasive insect pest that incites damage to ornamental and 16 agronomic crops on a global scale. In this study, the effects of temperature on gene expression and 17 enzyme activity were studied for superoxide dismutase (SOD), peroxidase (POD), and glutathione-

18 S-transferase (GST) in F. occidentalis. SOD, POD and GST enzyme activity increased

19 significantly at $35-37^{\circ} \mathrm{C}$ but declined as the temperature increased to $41^{\circ} \mathrm{C}$. In a time course study

20 at $35^{\circ} \mathrm{C}, \mathrm{SOD}, \mathrm{POD}$ and GST activities were significantly elevated at $0.5,1$ and $2 \mathrm{~h}$ in comparison

21 to the control at $26^{\circ} \mathrm{C}$. Expression patterns were evaluated for the three antioxidant genes under

22 high and low temperature stress. In a time course study at $-4^{\circ} \mathrm{C}, S O D, P O D$ and $G S T$ expression

23 peaked at $1 \mathrm{~h}$ and declined at $2 \mathrm{~h}$ of exposure. In contrast, when transcription was monitored at

$2435^{\circ} \mathrm{C}$, expression was lowest at $1 \mathrm{~h}$ and increased at $2 \mathrm{~h}$. The results provide data that will be useful

25 in deciphering the role of antioxidant enzymes in the adaptation of $F$. occidentalis to climate 26 change.

Keywords Frankliniella occidentalis; thermal stress; oxidative defense; enzymatic activity; gene expression 


\section{Introduction}

32 Temperature impacts the reproduction, development, and distribution of insects (Cossins \& Bowle 1987; Worner 1998; Bale et al. 2002), and extreme temperatures are known elicitors of reactive oxygen species (ROS) in invertebrates. The excessive generation of ROS can damage cellular constituents, including lipids, proteins, and nucleic acids (Halliwell 1989; Kamata \& Hirata 1999; Foyer \& Noctor 2005; Lopez-Martinez et al. 2008). In order to survive, insects reduce or detoxify ROS through the action of antioxidants; these function as enzymatic and non-enzymatic scavengers that reduce lipid peroxidation and decrease damage to nucleic acids and proteins (Felton \& Summers 1995; Lyakhovich et al. 2006; Krishnan et al. 2007). Peroxidase (POD), superoxide dismutase (SOD), and glutathione-S-transferase (GST) are antioxidant enzymes that defend cells from excessive levels of ROS (Felton \& Summers 1995; Wang et al. 2001; Dubovskiy et al. 2008; Liu et al. 2020). SOD functions by degrading superoxide anions to hydrogen peroxide $\left(\mathrm{H}_{2} \mathrm{O}_{2}\right)$ and oxygen, and $\mathrm{H}_{2} \mathrm{O}_{2}$ is subsequently converted to $\mathrm{H}_{2} \mathrm{O}$ by POD (Kashiwagi et al. 1997; Wang \& Li 2002; Liu \& Ma 2007). GSTs function to detoxify compounds that are produced from lipid peroxidation (Ahmad et al. 1991; Kono \& Shishido 1992; Dubovskiy et al. 2008). ornamental plants on a global scale and is especially problematic in greenhouses (Morse \& Hoddle 2006; Kirk \& Terry 2015; Mouden et al. 2017). In addition to direct damage, WFT causes serious damage to plants by transmitting plant viruses such as the Tomato Spotted Wilt Virus (Pappu et 
51 globally due to the transportation of agricultural products (Reitz 2009; Kirk \& Terry 2015).

52 According to the CABI Invasive Species Compendium, F. occidentalis has been discovered on all

53 continents except Antarctica (https://www.cabi.org/isc/datasheet/24426). In mainland China, $F$.

54 occidentalis was initially found in Beijing in 2003 (Zhang et al., 2003) and has since been

55 discovered in at least ten provinces (Wu et al. 2017).

56 Previous studies indicated that temperature impacts development, sex ratios, reproduction,

57 population growth, and mortality of $F$. occidentalis (Li et al. 2007; Li et al. 2011a; Zhang et al.

58 2012). During the hot summers in subtropical China, high temperatures may cause oxidative stress

59 to F. occidentalis, particularly in greenhouses (Wang et al. 2014). Previous studies demonstrated

60 that the expression of genes encoding catalase (CAT) and subsequent enzymatic activity were

61 altered in F. occidentalis exposed to hot and cold stress (Shi et al. 2013; Qin et al. 2017). However,

62 the impact of high and low temperatures on other antioxidant enzymes in F. occidentalis is unclear.

63 In this study, we investigated the effect of temperature stress on POD, SOD, and GST in $F$.

64 occidentalis. The results provide important data on how antioxidant enzymes counteract oxidative

65 damage in the WFT and provide a more comprehensive framework for understanding thermal

66 tolerance in F. occidentalis.

67

68 Materials \& Methods

69 Insects and temperature treatments 
70 Frankliniella occidentalis populations were collected in Hangzhou, China, in 2008 and were

71 reared with kidney bean, Phaseolus vulgaris Linn, at $25 \pm 0.5^{\circ} \mathrm{C}$ and $70 \pm 5 \%$ relative humidity with

72 a 16:8 h light:dark photoperiod as outlined by Li et al. (2011b). Newly emerged $2^{\text {nd }}$ instar larvae

73 were collected, and pools of 100 were exposed to high $\left(31,33,35,37,39\right.$ or $\left.41^{\circ} \mathrm{C}\right)$ or low $(0,-2$,

$74-4,-6,-8$ and $-10^{\circ} \mathrm{C}$ ) temperatures for $1 \mathrm{~h}$ in glass tubes as described (Chang et al., 2017). Through

75 the results of the pre-experiment, $35^{\circ} \mathrm{C}$ and $-4^{\circ} \mathrm{C}$ were decided as the model temperature on $F$.

76 occidentalis, which was further explored by subjecting groups of individuals to $0,0.5,1$, and $2 \mathrm{~h}$

77 of thermal stress; controls were maintained at $26^{\circ} \mathrm{C}(0 \mathrm{~h}$ time point $)$. Following thermal stress,

78 larvae were incubated at $26^{\circ} \mathrm{C}$ for $30 \mathrm{~min}$ and used a brush to touch it gently, thrips would be

79 identified as surviving if it respond to the stimulus. Survivors were frozen in liquid nitrogen and

80 stored at $-80^{\circ} \mathrm{C}$ for future use. Four replicate pools were used for each temperature and time period.

\section{Determination of enzyme activity}

83 The assay kit used for protein extraction was from Nanjing Jiancheng Bioengineering Institute,

84 Jiangsu, China. Treated samples were homogenized in $0.9 \%$ saline and then centrifuged at 2,500

$85 \times$ rpm for $10 \mathrm{~min}(\mathrm{Jia}$ et al., 2011). Supernatants containing the enzyme fractions were collected, 86 and protein content was determined using the Bradford (1976) method.

87 POD and SOD activities were assessed with commercially available kits (Qin et al., 2017).

88 Absorbance values were obtained using the BioTek PowerWave HT Microplate 
89 Spectrophotometer (Bio-Tek Instruments Inc., USA). GST activity was measured as a function of 90 reduced glutathione (GSH) using $10 \mathrm{mg}$ of cytosolic protein and 1-chloro-2,4-dinitrobenzene

91 (CDNB; Shanghai Chem, Shanghai, China) as a substrate (Habig et al., 1974; Attig et al., 2014).

92 GST activity was determined at $A_{340}$ with a microplate spectrophotometer (Shanghai Xinmao

93 Instrument, Shanghai, China), and results are shown as $\mu \mathrm{mol}$ GSH-CDNB/min/mg protein.

RNA isolation, partial cloning of $S O D, P O D$ and $G S T 1$, and qRT-PCR

The SV Total RNA Isolation System was used to isolate RNA from F. occidentalis as recommended by the manufacturer (Promega, San Luis Obispo, CA, USA). RNA quality and concentration were determined, and cDNA was generated from total RNA with the First Strand cDNA Synthesis Kit (Clontech, Mountain View, CA, USA) as outlined previously (Zhang et al., 2019). with the Sequence Read Archives PRJNA73493 at NCBI. To remove adapter contamination, low - quality bases and bases artificially introduced during library construction, we trimmed all

raw reads using Trimmomatic 0.32 (http://www.usadellab.org/ 
108 discarded (A.M. Bolger et al., 2014). The clean reads were mapped to the sequences in the rRNA

109 database of all published insects downloaded from NCBI to discard rRNAs using SOAP. Only the

110 clean reads with the standard of $\mathrm{Q} 30>85 \%$ and processed with Trimmomatic 0.32 and SOAP

111 were used for further analysis (X.Y. Gu et al., 2019). Clean data were assembled with Trinity to

112 obtain a high-quality unigene library (M.G. Grabherr et al., 2011). The unigene library of three

113 species were first assembled to obtain individual UniGene databases; the general UniGene library

114 was obtained by clustering the three individual databases through CD-Hit to facilitate comparison

115 of expression patterns (L. Fu et al., 2012). The transcripts selected in the clustering united as

116 unigenes using the De Bruijn graph algorithm; CD-Hit was used to reduce sequence redundancy

117 and improve the performance of other sequence analyses (L. Fu et al., 2012; Y. Yang et al., 2013).

118 For functional annotation, we obtained information on unigenes using BLAST (cut-off e-value of

119 10-5) with protein databases such as NR (NCBI nonredundant database), Swiss-Prot, GO (Gene

120 Ontology), COG (Clusters of Orthologous Groups), KOG (euKaryotic Orthologous Groups),

121 eggNOG, Pfam (Protein family) and KEGG (Kyoto Encyclopedia of Genes and Genomes). "

122 Superoxide Dismutase ", " Peroxidase " and " glutathione-s-transferase " were used as key words

123 to search related gene fragments in the transcriptome database of $F$. occidentalis, respectively.

124 The fragment gene cDNA of the SOD, GST1 and POD was

125 submitted to GenBank (accession no. MZ364120, MZ364118 and MZ364119, respectively).

126 According to the obtained gene fragments, the corresponding primers (Table 1) were designed for 
127 fragment verification. PCR products were cloned and sequenced as described (Zhang et al., 2019).

Quantitative real-time reverse transcriptase PCR (qRT-PCR) was conducted using the

129 protocols described by Zhang et al. (2019). Specific primers (Table 1) were designed according to

130 the above verified fragments for qRT-PCR. Melting curve analysis was executed to analyze the

131 specificity of PCR products. According to the evaluation results of Zheng et al. (2014) on the

132 reliability of reference genes in $F$. occidentalis, expression levels were normalized using reference

133 genes GAPDH, RPL32 and EF-1, $18 S$ for high and low temperature stress, respectively.

\section{Statistical analyses}

136 qRT-PCR data analyzing was conducted in Bio-Rad CFX Manager 3.1 software. The average Ct

137 values of biological replicates were used to calculate the relative expression levels. The results of

138 qPCR were analyzed with the $2^{-\Delta \Delta C t}$ method (Livak and Schmittgen 2001). Firstly, for all test

139 samples and calibration samples, the $\mathrm{Ct}$ value of the housekeeping gene were used to normalize

140 the $\mathrm{Ct}$ value of the target gene. Normalized results were $\Delta \mathrm{Ct}($ test) and $\Delta \mathrm{Ct}$ (calibrator),

141 respectively. And using $\Delta \mathrm{Ct}$ (calibrator) to normalize $\Delta \mathrm{Ct}$ (test), $\Delta \Delta \mathrm{Ct}$ was obtained. The ratio of

142 expression level was calculated by $2^{-\Delta \Delta \mathrm{Ct}}$. The $\lg (\mathrm{X})$ method was used to transform the expression

143 level data for normality and homogeneity of variance. Significant differences were detected by

144 one-way analysis of variance (ANOVA) and Duncan's multiple comparisons test. Data were

145 analyzed with SPSS v. 16.0 and considered significant at $P<0.05$. 


\section{Results}

\section{Effect of high temperature stress on antioxidant activity}

149 SOD activity increased with rising temperature from 31 to $37^{\circ} \mathrm{C}$ and was highest at $37^{\circ} \mathrm{C}$. The

150 activity of SOD activity began to decline at $39^{\circ} \mathrm{C}$, and the level at $41^{\circ} \mathrm{C}$ was significantly lower

151 than $37^{\circ} \mathrm{C}\left(F_{6,19}=4.245, P<0.05\right)$ (Fig. 1A). A similar pattern was observed with POD, where

152 activity rose with increasing temperature, peaked at $35^{\circ} \mathrm{C}$ and was significantly lower at $41^{\circ} \mathrm{C}$ than

$15335^{\circ} \mathrm{C}\left(F_{6,21}=7.089, P<0.05\right)$ (Fig. 1B). GST activity was highest at $35^{\circ} \mathrm{C}$ (Fig. 1C) and began to

154 decline with increasing temperature $\left(F_{6,21}=8.312, P<0.05\right)$.

155

156 Temporal changes in antioxidant enzyme activity at $35^{\circ} \mathrm{C}$

157 Antioxidant enzyme activity was significantly higher than the control $\left(0 \mathrm{~h}, 26^{\circ} \mathrm{C}\right)$ when insects

158 were exposed to $35^{\circ} \mathrm{C}$ for $0.5,1$ and 2 (SOD: $F_{3,10}=10.005, P<0.05$; POD: $F_{3,12}=8.037, P<0.05$;

159 GSTs: $\left.F_{3,10}=5.815, P<0.05\right)$. No significant differences in antioxidant activity were detected

160 between $0.5,1$ and $2 \mathrm{~h}$ of exposure (Fig. 2).

161

162 Expression of antioxidant genes in response to heat and cold stress

163 The expression of antioxidant genes was evaluated at $31,33,35,37,39$ and $41^{\circ} \mathrm{C} ; 26^{\circ} \mathrm{C}$ served as 
164 a control. $S O D$ expression showed significant decreases in expression at $35^{\circ} \mathrm{C}$ to $37^{\circ} \mathrm{C}$; however,

165 expression peaked at $39^{\circ} \mathrm{C}$ and was comparable to the control $\left(26^{\circ} \mathrm{C}\right)$ (Fig. 3A). With the exception

166 of $35^{\circ} \mathrm{C}$ to $37^{\circ} \mathrm{C}$, SOD expression was not significantly changed by high temperatures

$167\left(F_{6,18}=29.203, P<0.05\right)$. In contrast, $P O D$ expression levels at $33^{\circ} \mathrm{C}, 37^{\circ} \mathrm{C}$ and $39^{\circ} \mathrm{C}$ were

168 significantly higher than the control at $26^{\circ} \mathrm{C}$; however, except that the expression level was

169 significantly decreased at $35^{\circ} \mathrm{C}$, there was no significant difference in the expression level of $31^{\circ} \mathrm{C}$

170 compared with the control $\left(F_{6,18}=51.745, P<0.05\right)$ (Fig. 3B). GST1 expression was suppressed or

171 unaffected relative to the control at all elevated temperatures $\left(F_{6,17}=32.682, P<0.05\right)$ (Fig. $\left.3 \mathrm{C}\right)$. All

172 three antioxidant genes shared a common insensitivity in response to high temperature. Even under

173 some temperatures, the expression level was higher than that of the control, but the relative

174 expression level was not very high. .

175 Expression of the three antioxidant genes was also evaluated in response to low temperature

176 stress at $0,-2,-4,-6,-8$ and $-10^{\circ} \mathrm{C}$. SOD expression showed a significant decline at all temperatures

177 relative to the control at $26^{\circ} \mathrm{C}$; although the expression of $-4^{\circ} \mathrm{C}$ was higher than other temperatures,

178 it was also inhibited by low temperature (Fig. 4A) $\left(F_{6,20}=243.607, P<0.05\right) . P O D$ expression was

179 also strongly inhibited, with the lowest expression appeared at $-6^{\circ} \mathrm{C}$. $\left(F_{6,18}=51.909, P<0.05\right)$ (Fig.

180 4B). Like $S O D$ and $P O D$, the GST1 expression were decreased compared with the control relative

181 with low temperature. $\left(F_{6,17}=32.682, P<0.05\right)$ (Fig. $\left.4 \mathrm{C}\right)$.

182 


\section{Temporal changes in the expression of antioxidant genes}

184 Compared to the control $\left(0 \mathrm{~h}, 26^{\circ} \mathrm{C}\right), S O D$ expression decreased significantly when $2^{\text {nd }}$ instar larvae

185 were exposed to $35^{\circ} \mathrm{C}$ for $0.5,1$ and $2 \mathrm{~h}\left(S O D: F_{3,12}=31.689, P<0.05\right)$ and was lowest at the $1 \mathrm{~h}$

186 exposure period (Fig. 5A). POD expression was significantly upregulated at $0.5 \mathrm{~h}$ and $2 \mathrm{~h}$ and was

187 higher than expression levels at 0 (control) and $1 \mathrm{~h}$, with the peak appeared at $2 \mathrm{~h} .\left(F_{3,12}=72.243\right.$,

$188 P<0.05$ ) (Fig. 5B). GST1 expression pattern was similar to POD (Fig. 5C). Although there was no

189 significant difference at $0.5 \mathrm{~h}$ compared to the control $\left(G S T 1: F_{3,11}=1709.476, P<0.05\right)$.

190 After exposure to $-4^{\circ} \mathrm{C}$, the expression levels of the three antioxidant genes decreased

191 significantly when compared to the control $\left(S O D: F_{3,10}=201.898, P<0.05 ; P O D: F_{3,11}=204.420\right.$,

$192 P<0.05 ;$ GST1: $\left.F_{3,10}=72.835, P<0.05\right)$. Interestingly, all three genes showed a peak in expression

193 after a $1 \mathrm{~h}$ exposure to $-4^{\circ} \mathrm{C}$; however, it should be noted that expression at $1 \mathrm{~h}$ was lower than the

194 control (Fig. 6).

195

196 Discussion

197 Insects are poikilotherms that are greatly impacted by temperature fluctuations (Cossins \& Bowler

198 1987; Worner 1998; Bale et al. 2002). When exposed to thermal stress, insects sustain oxidative

199 damage at the cellular level and respond with surplus levels of ROS (Lopez-Martinez et al. 2008;

200 Cui et al. 2011; Li \& Sattar 2019). ROS can cause direct damage to biological macromolecules

201 and can also incite genetic mutations and cell death (Ryter et al. 2007). Antioxidant enzymes 
202 function to eliminate or reduce ROS levels in insects. Previous studies showed that SOD, POD

203 and GST play important roles in the response of insects to ROS (Abele et al. 1998; An \& Choi

204 2010; Celino et al. 2011; Liu et al. 2020). In this study, SOD, POD and GST activity increased

205 significantly in response to high temperatures, which suggests that these enzymes function to

206 remove excess ROS during thermal stress. Thus, our results are consistent with those reported for

207 Bactrocera dorsalis, Bombyx mori, Mononychellus mcgregori, Diaphorina citri and Neoseiulus

208 cucumeris (Lee et al. 2005; Jia et al. 2011; Marutani-Hert et al. 2010; Lu et al. 2014; Zhang et al.

2092014 ). In a previous report, low temperature stress significantly altered SOD, POD, CAT and GST

210 activity in F. occidentalis (Shi et al. 2013). The increase in POD activity was likely the result of

211 elevated levels of SOD activity in response to $\mathrm{H}_{2} \mathrm{O}_{2}$. Although increased levels of antioxidant

212 enzymes suggests a defensive function of these enzymes in counteracting the negative effect of

213 ROS, there were no significant differences in SOD, POD or GST activity at $0.5,1.0$ and $2.0 \mathrm{~h}$ of

214 exposure to $35^{\circ} \mathrm{C}$ (Fig. 2). This might indicate that antioxidant enzyme activity is very sensitive to

215 high temperature stress and reached a threshold level at $0.5 \mathrm{~h}$ or earlier.

216 Many researchers have shown that temperature stress can lead to changes in antioxidant gene

217 expression in insects (Yang et al. 2019; Xia et al. 2019; Lu et al. 2017). Previous results showed

218 that temperature stress inhibited the transcription of SOD, POD, GST1 and related enzymes in

219 Mythimna separate, Apis cerana cerana and Helicoverpa armigera (Shen et al. 2016; Yang et al.

220 2019; Xia et al. 2019). These results reflect the diversity of molecular responses in organisms

221 exposed to external stress. In addition to recruiting antioxidant enzymes to remove ROS in

Peer) reviewing PDF | (2021:02:58282:3:0:NEW 29 Jul 2021) 
222

223

224

225

226

227

228

229

230

231

232

233

234

235

236

237

238

239

240

241

response to thermal stress, insects also respond by synthesizing osmoprotectants, altering membrane lipid content, and expressing heat shock proteins (Chen \& Kang 2005). A previous study demonstrated that both high and low thermal stress induced $C A T$ expression in $F$. occidentalis (Qin et al. 2017); therefore, the down-regulation of $P O D$ in this study might be attributed to increased expression of $C A T$. In the case of $S O D$ and $G S T 1$, thermal stress may induce the synthesis of unknown substances that could inhibit transcription. Further research is needed to validate or disprove these conjectures.

Differential regulation of antioxidant genes and enzymes has been reported in insects; for example, $P O D, C A T$ and $S O D$ expression patterns were not necessarily correlated with enzyme activity during high temperature stress in Mononychellus mcgregori (Lu et al. 2017). In larvae of Bombyx mori, carboxylesterase activity was not correlated with gene expression (Liu et al. 2010). Elevated protein levels can be stressful for the organism, and the organism may inhibit gene transcription to maintain homeostasis. Conversely, if protein levels fall to a suboptimal level, the cell may respond by promoting transcription. Furthermore, transcription is often followed by posttranscriptional processing, degradation of transcription products, translation, post-translational processing and further modifications that impact protein levels. Further research is needed to understand the mechanisms that control the response of $F$. occidentalis to thermal stress.

\section{Conclusions}

This study reveals differential regulation of antioxidant gene expression and enzyme production 
242 in response to thermal stress. The results confirm the importance of antioxidant enzymes in

243 modulating the response to thermal stress in $F$. occidentalis, and provide new avenues for further

244 study of antioxidant mechanisms and physiological responses of $F$. occidentalis. The

245 inconsistencies between gene expression and enzyme activity further illustrate the complexity of

246 thermal adaptation in $F$. occidentalis. Future multidisciplinary research in genomics,

247 transcriptomics, proteomics, and metabolomics will help explain the underlying mechanisms of

248 thermal adaptation in F. occidentalis.

250 Acknowledgments

251 We express our deep gratitude to the Testing Center of Yangzhou University. The authors

252 acknowledge support from the Special Fund for Agro-Scientific Research in the Public Interest of

253 China $(201103026,200803025)$.

\section{References}

255 Abele D, Burlando B, Viarengo A \& Pörtnera H O. 1998. Exposure to elevated temperatures 256 and hydrogen peroxide elicits oxidative stress and antioxidant response in the Antarctic 257 intertidal limpet Nacella concinna. Comparative Biochemistry and Physiology B: 258 Biochemistry and Molecular Biology 120, 425-435.

259 Ahmad S, Duval D L, Weinhold L C \& Pardini R S. 1991. Cabbage looper antioxidant 260 enzymes: tissue specificity. Insect Biochemistry 21, 563-572.

261 A.M. Bolger, M. Lohse, B. Usadel. 2014. Trimmomatic: a flexible trimmer for Illumina 262 sequence data, Bioinformatics 30, 2114-2120.

An M I \& Choi C Y. 2010. Activity of antioxidant enzymes and physiological responses in 
264 ark shell, Scapharca broughtonii, exposed to thermal and osmotic stress: effects on 265 hemolymph and biochemical parameters. Comparative Biochemistry and Physiology B: 266 Biochemistry and Molecular Biology 155, 34-42.

267 Bale J S, Masters G J, Hodkinson I D, Awmack C, Bezemer TM, Brown VK, Butterfield J, 268 Buse A, Coulson JC, Farrar J, Good JEG, Symrnioudis I, Watt AD, Whittaker JB . 2002. 269 Herbivory in global climate change research: direct effects of rising temperature on insect 270 herbivores. Global Change Biology 8, 1-16.

271 Bradford M M. 1976. A rapid and sensitive method for the quantitation of microgram 272 quantities of protein utilizing the principle of protein-dye binding. Analytical Biochemistry $273 \quad \mathbf{7 2}, 248-254$.

274 Celino F T, Yamaguchi S, Miura C, Ohta T, Tozawa Y, Iwai T, Miura T. 2011. Tolerance of 275 spermatogonia to oxidative stress is due to high levels of $\mathrm{Zn}$ and $\mathrm{Cu} / \mathrm{Zn}$ superoxide dismutase. $276 \quad$ PLOS ONE 6, e16938.

277 Chang Y-W, Chen J-Y, Lu M-X, Gao Y, Tian Z-H, Gong W-R, et al. 2017. Selection and 278 validation of reference genes for quantitative real-time PCR analysis under different 279 experimental conditions in the leafminer Liriomyza trifolii (Diptera: Agromyzidae). PLoS $280 \quad$ ONE 12(7), e0181862.

281 Chen B and Kang L. 2005. Adaptation of insects to environmental temperature stress and 282 population differentiation. Progress in Natural Science. (03), 11-17.

283 Cossins A R, Bowler K. (Eds.) 1987. Temperature Biology of Animals. Chapman and Hall, $284 \quad$ New York, pp. 125-157.

285 Cui Y D, Du Y Z, Lu M X \& Qiang C K. 2011. Antioxidant responses of Chilo suppressalis 286 (Lepidoptera: Pyralidae) larvae exposed to thermal stress. Journal of Thermal Biology 36, 287 292-297.

288 Dubovskiy I M, Martemyanov V V, Vorontsova Y L, Rantala M J, Gryzanova E V \& Glupov 289 V V. 2008. Effect of bacterial infection on antioxidant activity and lipid peroxidation in the 
midgut of Galleria mellonella L. larvae (Lepidoptera, Pyralidae). Comparative Biochemistry and Physiology Part C Toxicology and Pharmacology 148, 1-5. Felton G W \& Summers C B. 1995. Antioxidant systems in insects. Archives of Insect Biochemistry and Physiology 29, 187-197.

Foyer C H \& Noctor G. 2005. Oxidant and antioxidant signalling in plant: a reevaluation of the concept of oxidative stress in a physiological context. Plant Cell and Environment 28, 1056-1071.

Habig W H, Pabst M J \& Jakoby W B. 1974. Glutathione S-Transferases. Journal of Biological Chemistry 249, 7130-7139. Hajer Attig, Naouel Kamel, Susanna Sforzini, Alessandro Dagnino, Jebali Jamel, Hamadi Boussetta, Aldo Viarengo, Mohamed Banni. 2014. Effects of thermal stress and nickel exposure on biomarkers responses in Mytilus galloprovincialis (Lam), Marine Environmental Research, 94, 65-71.

Halliwell B. 1989. Free-radicals, reactive oxygen species and human disease-acritical evaluation with special reference to atherosclerosis. British Journal of Experimental Pathology 70, 737-757.

Jia F X, Dou W, Hu F \& Wang J J. 2011. Effects of thermal stress on lipid peroxidation and antioxidant enzyme activities of oriental fruit fly, Bactrocera dorsalis (Diptera: Tephritidae). Florida Entomologist 94, 956-963. Kamata H \& Hirata H. 1999. Redox regulation of cellular signalling. Cellular Signalling 11, $1-14$

Kashiwagi A, Kashiwagi K, Takase M, Hanada H \& Nakamura M. 1997. Comparison of catalase in diploid and haploid Rana rugosa using heat and chemical inactivation techniques. Comparative Biochemistry and Physiology B: Biochemistry and Molecular Biology 118, 499503. 
316 occidentalis (Pergande). Agricultural and Forest Entomology 5, 301-310.

317 Kono Y \& Shishido T. 1992. Distribution of glutathione S-transferase activity in insect 318 tissues. Applied Entomology and Zoology 27, 391-397.

319 Krishnan N, Kodrík D, Turanli F \& Sehnal F. 2007. Stage-specific distribution of oxidative 320 radicals and antioxidant enzymes in the midgut of Leptinotarsa decemlineata. Journal of $321 \quad$ Insect Physiology 53, 67-74.

322 Lee KS, Kim SR, Park NS, Kim I, Kang PD, Sohn BH, Choi KH, Kang SW, Je YH, Lee SM, 323 Sohn HD, Jin BR. 2005. Characterization of a silkworm thioredoxin peroxidase that is 324 induced by external temperature stimulus and viral infection. Insect Biochemistry and $325 \quad$ Molecular Biology 35, 73-84.

326 L. Fu, B. Niu, Z. Zhu, S. Wu, W. Li. 2012. CD-HIT: accelerated for clustering the next327 generation sequencing data, Bioinformatics 28, 3150-3152.

328 Li H B, Shi L, Lu M X, Wang J J \& Du Y Z. 2011a. Impact of temperature hardening on 329 thermal tolerance and reproduction in Frankliniella occidentalis. Chinese Journal of Applied $330 \quad$ Entomology 36, 437-442.

331 Li H B, Shi L, Lu M X, Wang J J \& Du Y Z. 2011b. Thermal tolerance of Frankliniella 332 occidentalis: effects of temperature, exposure time and gender. Journal of Thermal Biology 333 36, 437-442.

334 Li J Z, Zhi J R, Yuan C M \& Wang H. 2007. The effect of temperature on the development 335 of Frankliniella occidentalis. Guizhou Agricultural Science 5, 1-5.

336 Li L J and Adili Sattar. 2019. Effect of temperature stress on the main antioxidant enzymes 337 in the pupa of Carpomya vesuviana Costa. Xinjiang Agricultural Sciences. 56(11), 20623382071.

339 Liu C M \& Ma J Q. 2007. Effects of different temperatures on cultivating and protection $340 \quad$ enzymes of Polyrhachis dives. Journal of Xuzhou Normal University 25, 72-74.

341 Liu H T, Li B, Zhao G D, Zhang T, Gao R N, Wei Z G, Shen W D. 2010. Sexual differences 
342 in main detoxification enzymes and their gene expression in different instars of Bombyx mori $343 \quad$ larvae. Acta Entomologica Sinica. 53(5), 479-486.

344 Liu Li, Hou Xiao Lin, Yue Wen Bo, Xie Wen, Zhang Tao, Zhi Jun Rui. 2020. Response of 345 Protective Enzymes in Western Flower Thrips (Thysanoptera: Thripidae) to Two 346 Leguminous Plants. Environmental entomology. 49(5), 1191-1197.

347 Livak KJ, Schmittgen TD. 2001. Analysis of relative gene expression data using real-time 348 quantitative PCR and the $2^{-\Delta \Delta C t}$ method. Methods 25(4), 402-408

349 Lopez-Martinez G, Elnitsky M A, Benoit J B, Lee R E \& Denlinger D L. 2008. High 350 resistance to oxidative damage in the Antarctic midge Belgica antarctica, and 351 developmentally linked expression of genes encoding superoxide dismutase, catalase, and 352 heat shock proteins. Insect Biochemistry and Molecular Biology 38, 796-804.

353 Lu F P, Chen Q, Chen Z H, Lu H, Xu X L \& Jing F L. 2014. Effects of heat stress on 354 development, reproduction and activities of protective enzymes in Mononychellus mcgregori. $355 \quad$ Experimental and Applied Acarology 63, 267-284.

356 Lyakhovich V V, Vavilin V A, Zenkov N K \& Menshchikova E B. 2006. Active defense 357 under oxidative stress. The antioxidant responsive element. Biochemistry Biokhimiia 71, 962$358 \quad 1183$

359 Marutani-Hert M, Hunter W B \& Hall D G. 2010. Gene response to stress in the Asian citrus 360 psyllid (Hemiptera: Psyllidae). Florida Entomologist 93, 519-525.

361 M.G. Grabherr, B.J. Haas, M. Yassour, J.S. Levin, D.A. Thompson, I. Amit, et al. 2011. Full362 length transcriptome assembly from RNA-Seq data without a reference genome, Nat. 363 Biotechnol. 29, 644-652.

364 Morse J G \& Hoddle M S. 2006. Invasion biology of thrips. Annual Review of Entomology $365 \quad \mathbf{5 1}, 67-89$.

366 Pappu H R, Jones R A \& Jain R K. 2009. Global status of tospovirus epidemics in diverse 367 cropping systems: successes achieved and challenges ahead. Virus Research 141, 219-236. 
Qin J, Lu M X, Zheng Y T \& Du Y Z. 2017. Molecular cloning, characterization and functional analysis of catalase in Frankliniella occidentalis. Annals of the Entomological Society of America 110, 212-220.

Reitz S R. 2009. Biology and ecology of the western flower thrips (Thysanoptera: Thripidae): The making of a pest. Florida Entomologist 92, 7-13. Ryter S W, Kim H P, Hoetzel A, Park JW, Choi AMK . 2007. Mechanisms of cell death in oxidative stress. Antioxid Redox Signal 9, 49-89. Shen S, Wang M, Li X, Li S, van Oers MM, Vlak JM, Braakman I, Hu Z, Deng F, Wang H. 2016. Mutational and functional analysis of N-linked glycosylation of envelope fusion protein F of Helicoverpa armigera nucleopolyhedrovirus. J Gen Virol. 97(4), 988-999. Shi L, Li H B, Kim H J., Wang J J \& Du Y Z. 2013. Effect of low temperature stress on antioxidase activity of western flower thrips, Frankliniella occidentalis. Chinese Journal of Applied Entomology 50, 1062-1067.

Tomitaka, Y. 2019. Studies on the interaction between tomato spotted wilt tospovirus and thrips. J. Gen. Plant Pathol. 85, 465-467.

Wang J C, Zhang B, Li H G, Wang J P \& Zheng C Y. 2014. Effects of Exposure to High Temperature on Frankliniella occidentalis (Thysanoptera: Thripidae), under Arrhenotoky and Sexual Reproduction Conditions. Florida Entomologist 97, 504-510. Wang M \& Li Z Z. 2002. Studies on the activities of enzymes of protective system during diapause of sawfly Chinolyda flagellicorni. Scientia Silvae Sinicae 38, 100-104.

Wang Y, Oberley L W \& Murhammer D W. 2001. Evidence of oxidative stress following the viral infection of two lepidopteran insect cell lines. Free Radical Biology and Medicine 30, 1254-1262.

Worner S P. 1998. Ecoclimatic assessment of potential establishment of exotic pests. Journal of Economic Entomology 81, 973-983.

Wu SY, Tang L D, Zhang X R, Xing Z L, Lei Z R \& Gao Y L. 2017. A decade of a thrips 
394 invasion in China: lessons learned. Ecotoxicology. 27(7), 1032-1038.

395 Xia Z Y, Qin M, Wang H F, Liu Z G, Wang Y, Zhang W X, Xu B H. 2019. Effect of low

396 temperature stress on antioxidant indexs and cold tolerance gene expression in Apis cerana

397 cerana during overwintering period. Chinese Journal of Animal Nutrition. 31(3), 1250-1258.

398 X.Y. Gu, Y. Zhao, Y. Su, J.J. Wu, Z.Y. Wang, J.T. Hu, L.J. Liu, Z.H. Zhao, A.A. Hoffmann,

399 B. Chen, Z.H. Li. 2019. A transcriptional and functional analysis of heat hardening in two

$400 \quad$ invasive fruit fly species, Bactrocera dorsalis and Bactrocera correcta, Evol. Appl 12, $1147-$

$401 \quad 1163$

402 Yang Hang, Wang Xiaoyun, Pei Haiying, Fan Dong. 2019. Cloning a Peroxidase cDNA

403 Sequence from the Oriental Armyworm, Mythimna separate Walker and Its Induction to

404 Different Temperature Stress. Chinese Journal of Biological Control. 35(01), 44-52.

405 Y. Yang, S.A. Smith. 2013. Optimizing de novo assembly of short-read RNA-seq data for 406 phylogenomics, BMC Genomic 14, 328.

407 Zhang G H, Liu H, Wang J J \& Wang Z Y. 2014. Effects of thermal stress on lipid 408 peroxidation and antioxidant enzyme activities of the predatory mite, Neoseiulus cucumeris 409 (Acari: Phytoseiidae). Enperimental and Applied Acarology. 64, 3-85.

410 Zhang X, Qin J, Yuan J, Lu M, Du Y. 2019. Cloning of a new HSP70 gene from western 411 flowerthrips, Frankliniella occidentalis, and expression patterns during thermal $412 \quad$ stress. PeerJ. 7, e7687

413 Zhang Y J, Wu Q J, Xu B Y \& Zhu G R. 2003. The occurrence and damage of Frankliniella 414 occidentalis (Thysanoptera: Thripidae): a dangerous alien invasive pest in Beijing. Plant $415 \quad$ Protection 4, 58-59.

416 Zhang Z J, Zhang Y J, Xu B Y, Zhu G R, Wu Q J. 2012. Effects of temperature on 417 development, reproduction and population growth of the western flower thrips, 418 Frankliniella occidentalis ( Thysanoptera: Thripidae). Acta Entomologica Sinica. 55(10), 419 $1168-1177$. 
420 Zheng Y T, Li H B, Lu M X, Du Y Z, 2014. Evaluation and validation of reference genes for 421 qRT-PCR normalization in Frankliniella occidentalis (Thysanoptera: Thripidae). PLos ONE, $422 \quad \mathbf{9 ( 1 0 )}, \mathrm{e} 111369$. 
Figure 1

Effect of high temperature stress on antioxidant enzyme activity in $2^{\text {nd }}$ instar larvae of $F$. occidentalis.

Panels: (A) SOD, superoxide dismutase; (B) POD, peroxidase; (C) GST, glutathione-S-

transferase. Larvae were exposed to $31,33,35,37,39$, and $41^{\circ} \mathrm{C}$ for $1 \mathrm{~h}$ in glass tubes; $26^{\circ} \mathrm{C}$ was used as the control. Each value represents the mean $( \pm S E)$ of four replications. Columns labeled with different letters indicate significance at $P<0.05$ using ANOVA ( Ducan 's test).
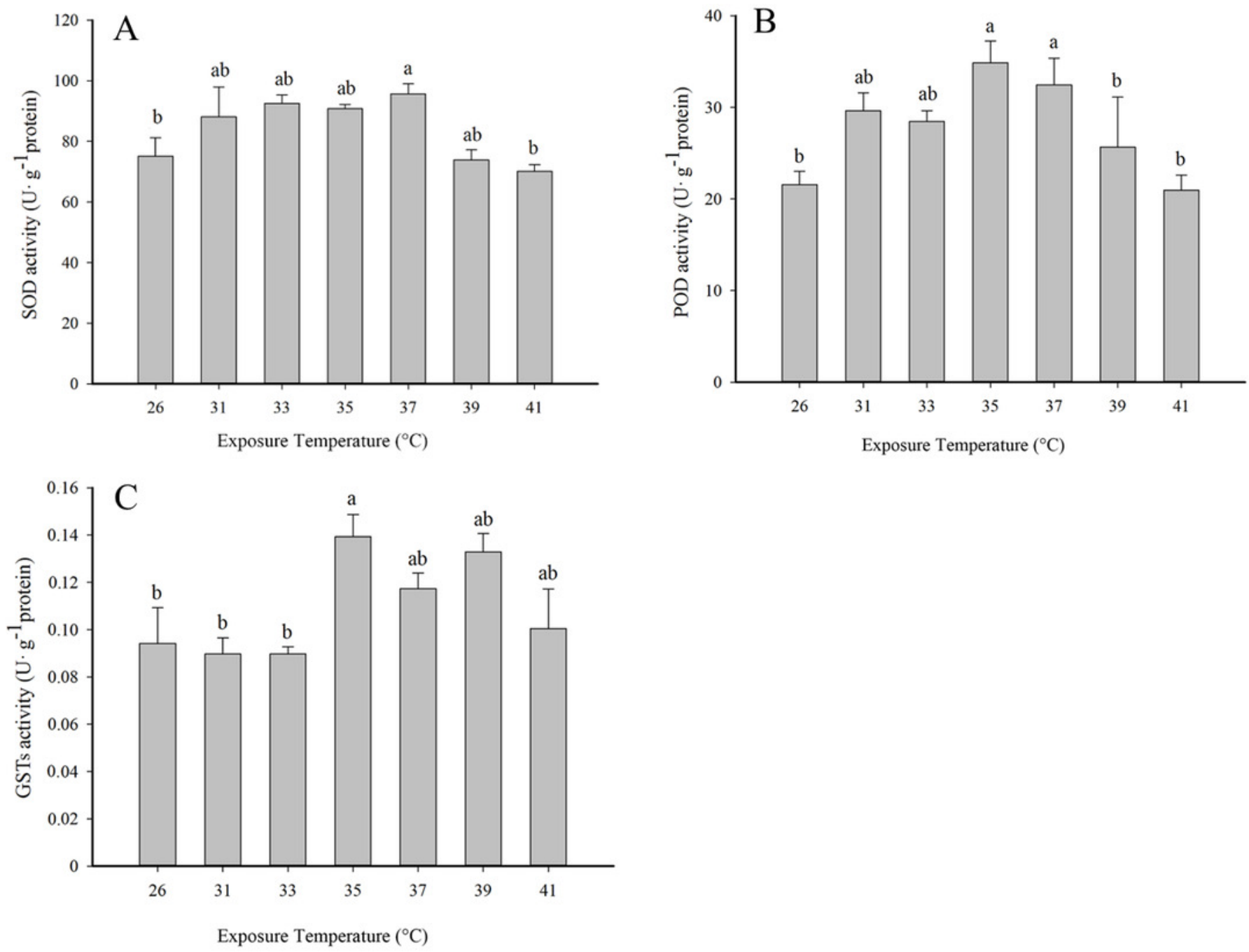


\section{Figure 2}

Temporal changes in antioxidant enzyme activity in $2^{\text {nd }}$ instar larvae of $F$. occidentalis exposed to $35^{\circ} \mathrm{C}$.

Panels: (A) SOD, superoxide dismutase; (B) POD, peroxidase; (C) GST, glutathione-Stransferase. F. occidentalis was exposed to $35^{\circ} \mathrm{C}$ for $0.5,1$, and $2 \mathrm{~h}$ and then analyzed for enzyme activity. The control group was maintained at $26^{\circ} \mathrm{C}$ ( $0 \mathrm{~h}$ time point). Columns show the mean ( $\pm \mathrm{SE}$ ) of four replications, and columns labeled with different letters indicate significance at $P<0.05$ in ANOVA ( Ducan 's test). 


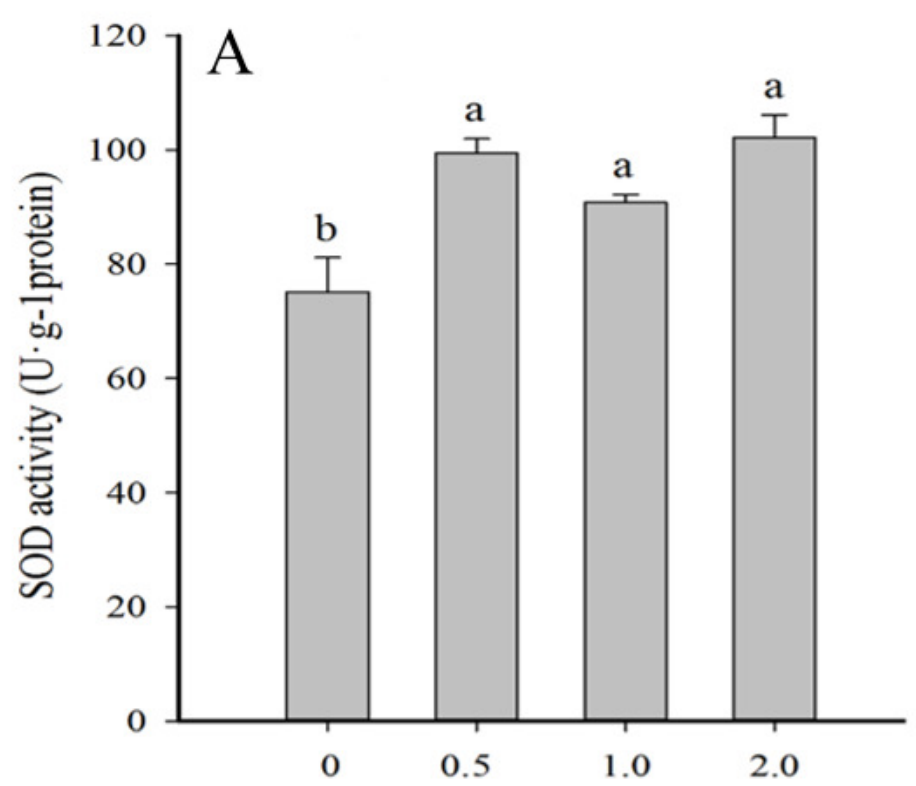

Exposure Time (h)

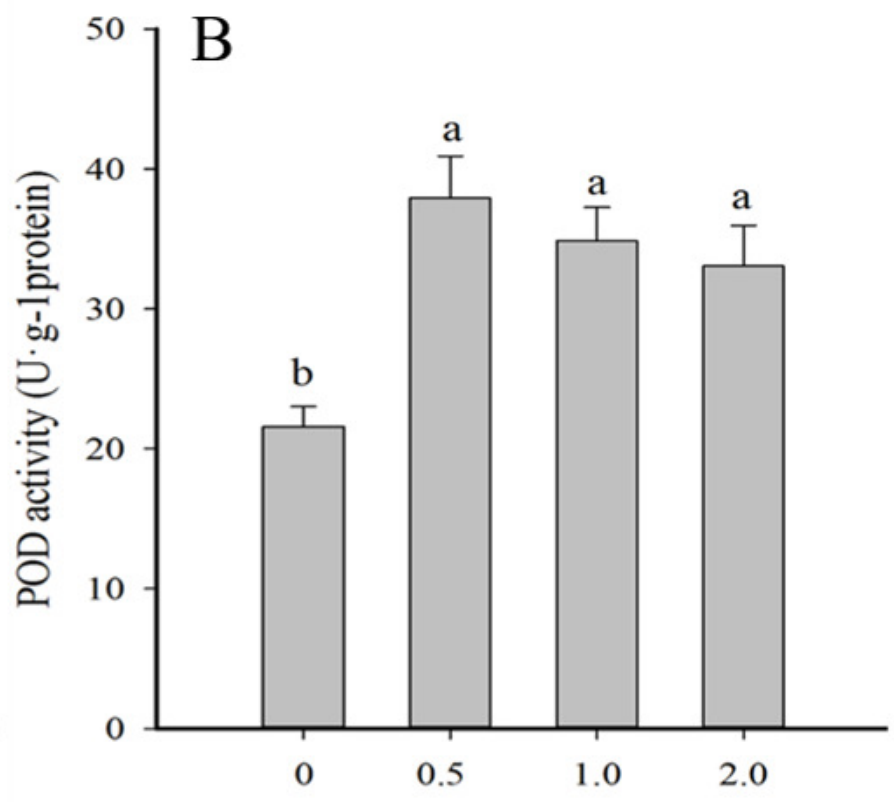

Exposure Time (h)

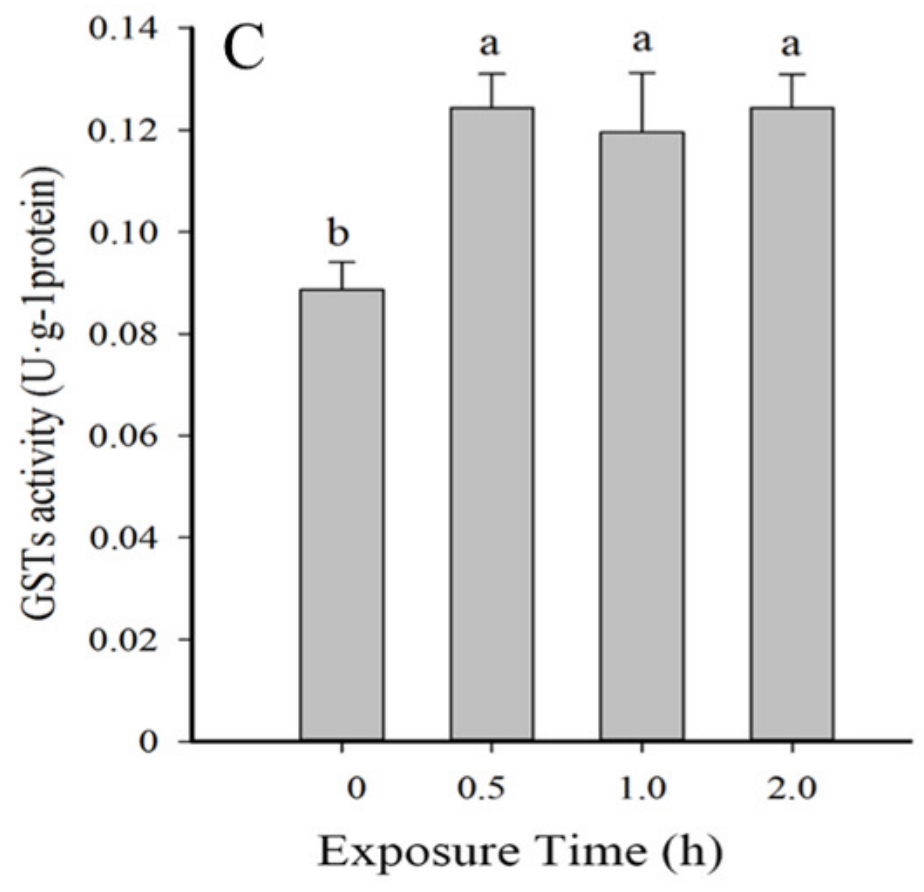


Figure 3

Effect of high temperature stress on expression of antioxidant genes in $2^{\text {nd }}$ instar larvae of $F$. occidentalis.

Panels: (A) SOD, superoxide dismutase; (B) POD, peroxidase; (C) GST, glutathione-S-

transferase. Larvae were exposed to $31,33,35,37,39$, and $41^{\circ} \mathrm{C}$ for $1 \mathrm{~h}$ in glass tubes; $26^{\circ} \mathrm{C}$ was used as the control. Expression levels were normalized with respect to GAPDH. Values represent the mean $( \pm S E)$ of four replications, and columns labeled with different letters indicate significance at $P<0.05$ in ANOVA ( Ducan 's test).
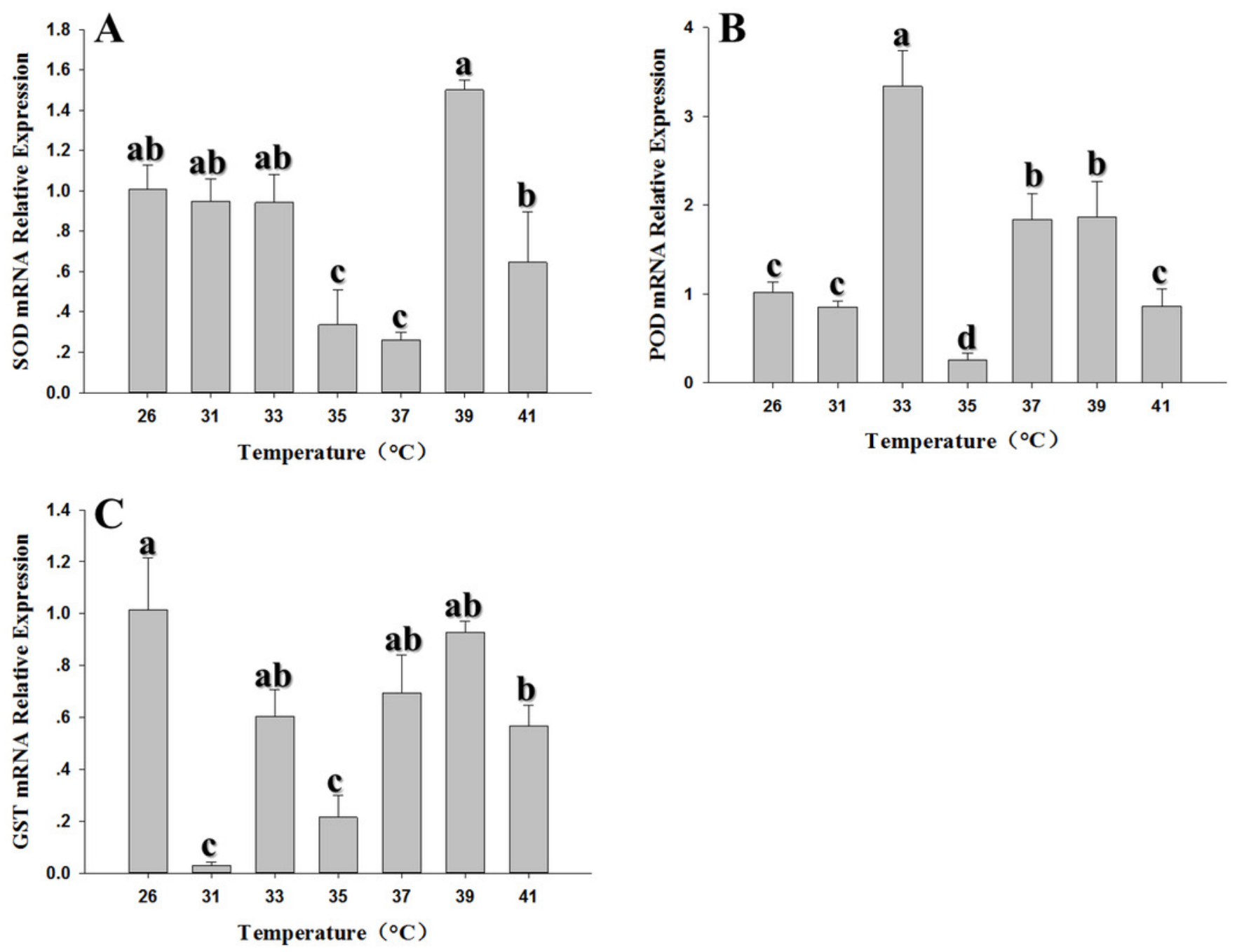
Figure 4

Effect of low temperature stress on expression of antioxidant genes in $2^{\text {nd }}$ instar larvae of $F$. occidentalis.

Panels: (A) SOD, superoxide dismutase; (B) POD, peroxidase; (C) GST, glutathione-Stransferase. Larvae were exposed to $0,-2,-4,-6,-8$ and $-10^{\circ} \mathrm{C}$ for $1 \mathrm{~h}$ in glass tubes; $26^{\circ} \mathrm{C}$ was used as the control. Expression levels were normalized with respect to EF-1. Values represents the mean ( $\pm \mathrm{SE}$ ) of four replications, and columns labeled with different letters indicate significance at $P<0.05$ in ANOVA (Ducan's test).
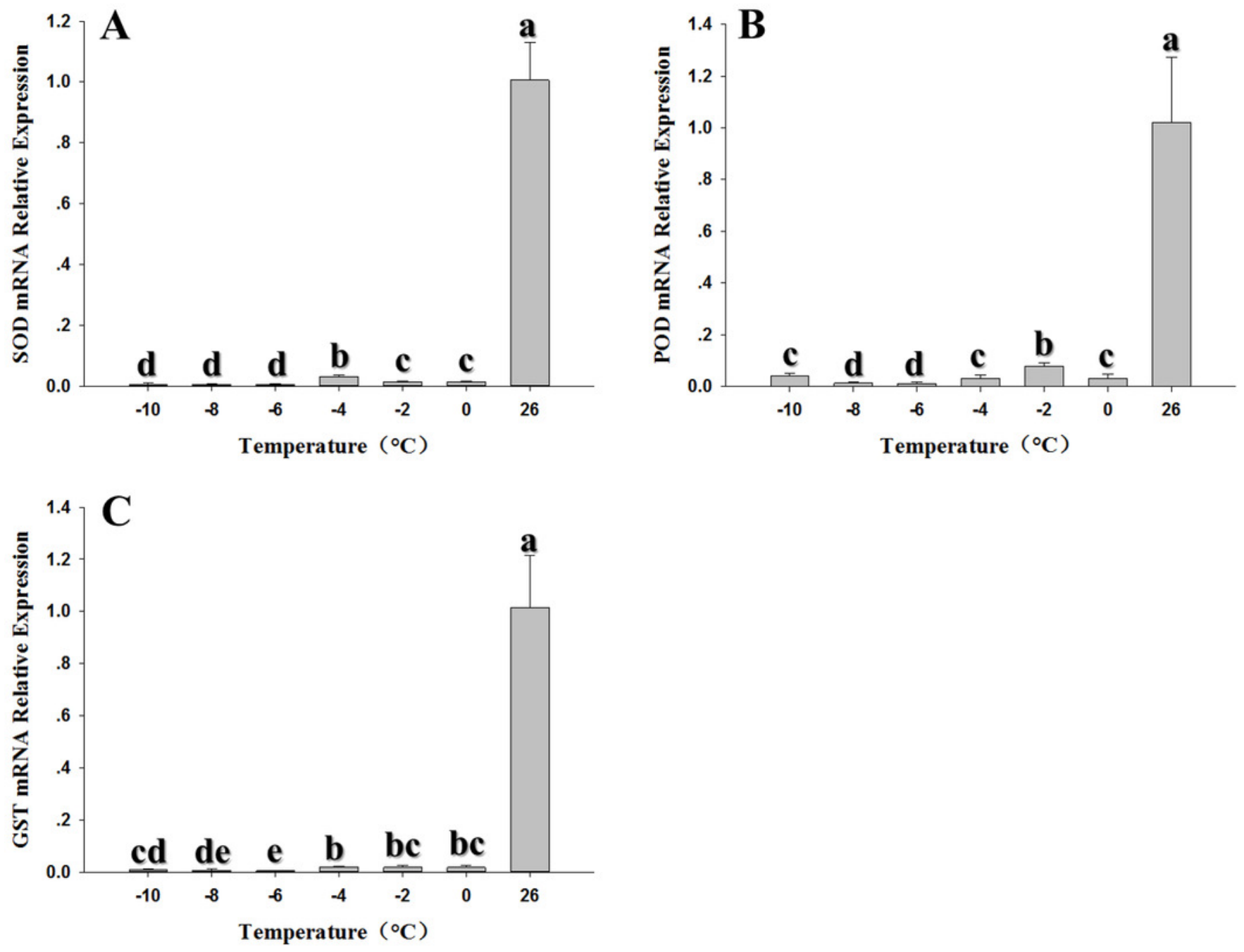


\section{Figure 5}

Temporal changes in the expression of antioxidant genes in $2^{\text {nd }}$ instar larvae of $F$. occidentalis exposed to $35^{\circ} \mathrm{C}$.

Panels: (A) SOD, superoxide dismutase; (B) POD, peroxidase; (C) GST, glutathione-Stransferase. F. occidentalis was exposed to $35^{\circ} \mathrm{C}$ for $0.5,1$, and $2 \mathrm{~h}$ and then analyzed for gene expression; the control group was maintained at $26^{\circ} \mathrm{C}$ ( $0 \mathrm{~h}$ time point). Expression levels were normalized with respect to GAPDH. Columns show the mean $( \pm S E)$ of four replications, and columns labeled with different letters indicate significance at $P<0.05$ in ANOVA ( Ducan 's test). 

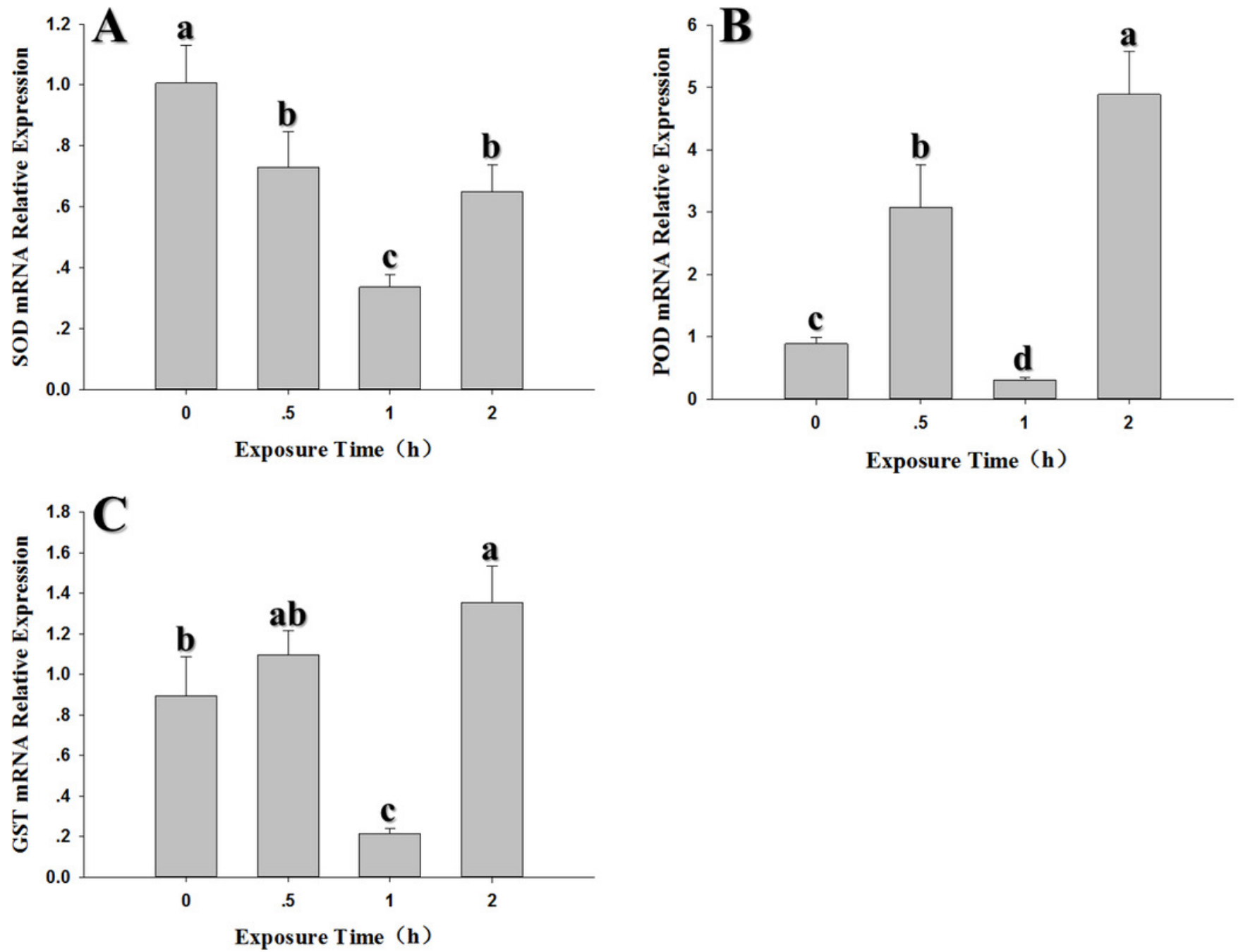


\section{Figure 6}

Temporal changes in the expression of antioxidant genes in $2^{\text {nd }}$ instar larvae of $F$. occidentalis exposed to $-4^{\circ} \mathrm{C}$.

Panels: (A) SOD, superoxide dismutase; (B) POD, peroxidase; (C) GST, glutathione-Stransferase. F. occidentalis was exposed to $4^{\circ} \mathrm{C}$ for $0.5,1$, and $2 \mathrm{~h}$ and then analyzed for gene expression; the control group was maintained at $26^{\circ} \mathrm{C}(0 \mathrm{~h}$ time point). Expression levels were normalized with respect to $E F-1$. Columns show the mean ( \pm SE) of four replications, and columns labeled with different letters indicate significance at $P<0.05$ in ANOVA (Ducan's test). 

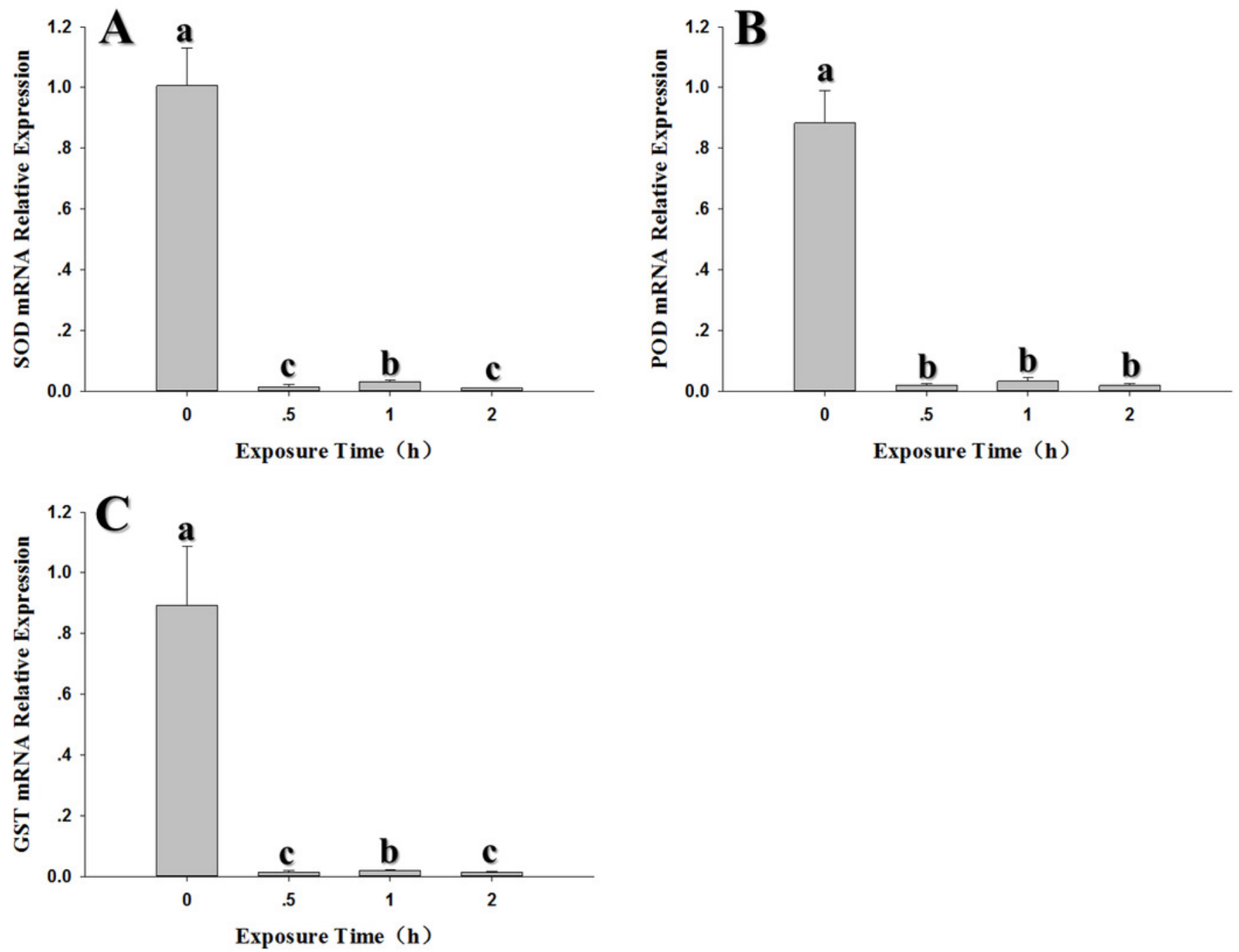
Table $\mathbf{1}$ (on next page)

Primers used in the study 


\begin{tabular}{|c|c|c|c|c|}
\hline Primer name & Primer sequences & $\operatorname{Tm}\left({ }^{\circ} \mathrm{C}\right)$ & Length (bp) & $\mathrm{E}^{\mathrm{c}}(\%)$ \\
\hline DP-SOD-F & AATGCTGCGTTCTCTGTTGTG & 58.7 & \multirow{2}{*}{335} & \\
\hline DP-SOD-R & TCTGGTTTTGTTGTTTCAGGAGT & 58.4 & & \\
\hline DP-POD-F & CAACCCCGACCAGCCCTAC & 62.3 & \multirow{2}{*}{600} & \\
\hline DP-POD-R & AAAAGGGGAAATCGGTGTCG & 61.4 & & \\
\hline DP-GST-F & TGACCGTGAACCAGACCGAG & 61.3 & \multirow{2}{*}{431} & \\
\hline $\mathrm{DP}-G S T$-R & GATGCCGAAAATACTGAGTGTGG & 61.4 & & \\
\hline qPCR-SOD-F & GAAATAACTGGTTCCAAGGCACT & 59.6 & \multirow{2}{*}{125} & \multirow{2}{*}{91.8} \\
\hline qPCR-SOD-R & AATGCTGCGTTCTCTGTTGTG & 58.7 & & \\
\hline qPCR-POD-F & CCGCACTGGGACGACGAGAC & 65.8 & \multirow{2}{*}{235} & \multirow{2}{*}{96.4} \\
\hline qPCR-POD-R & CGATGAGCGAGTGGAAGTATCTGAA & 64.8 & & \\
\hline qPCR-GST-F & GCTGCTGCTGTGCTGGATTA & 59.7 & \multirow{2}{*}{170} & \multirow{2}{*}{90.0} \\
\hline qPCR-GST-R & ACCGTGAACCAGACCGAGAC & 59.4 & & \\
\hline$E F-1-\mathrm{F}$ & TCAAGGAACTGCGTCGTGGAT & \multirow{2}{*}{58.6} & \multirow{2}{*}{130} & \multirow{2}{*}{95.4} \\
\hline$E F-1-\mathrm{R}$ & ACAGGGGTGTAGCCGTTAGAG & & & \\
\hline $18 S-\mathrm{F}$ & AACACGGGAAACCTCACCA & \multirow{2}{*}{55.4} & \multirow{2}{*}{116} & \multirow{2}{*}{108.9} \\
\hline $18 S-\mathrm{R}$ & CAGACAAATCGCTCCACCAA & & & \\
\hline RPL32-F & CAACATCGGTTATGGAAGCA & \multirow{2}{*}{55.0} & \multirow{2}{*}{141} & \multirow{2}{*}{100.1} \\
\hline RPL32-R & ACAGCGTGGGCAATTTCAGC & & & \\
\hline$G A P D H-F$ & AAGGGTGCTCAGGTTGTTGCT & \multirow{2}{*}{56.5} & \multirow{2}{*}{89} & \multirow{2}{*}{104.4} \\
\hline$G A P D H-\mathrm{R}$ & CGACCGTGGGTGGAGTCATAT & & & \\
\hline
\end{tabular}

